\title{
Research on the tenants' willingness to vacate public rental housing based on ordered Logistic model-A Case of Wuhan
}

\author{
Ziyuan Tian ${ }^{1, a}$ \\ ${ }^{1}$ School of Civil Engin., Architecture and Environment, \\ Hubei Univ. of Tech, Wuhan 430068, China \\ a403338783@qq.com
}

\begin{abstract}
Keywords: public rental housing, willingness to vacate, ordered logistic model, Wuhan.
\end{abstract}
\begin{abstract}
From the perspective of public rental housing tenants, this paper studies the influential factors of tenants' willingness to vacate.A questionnaire survey was conducted on tenants' willingness to vacate public rental housing in Wuhan city. Statistical data were processed and regression analysis was conducted using the ordered logistic model to study the correlation between factors affecting tenants' willingness to vacate and the confidence to solve their own housing.It is found that the construction area of public rental housing, the tenants' understanding of the nature of public rental housing and the understanding of the legal system of public rental housing are the key factors influencing the tenants' vacating behaviors.
\end{abstract}

\section{Introduction}

The 12th Five-Year Plan suggests that the purpose of affordable housing construction is to establish a housing supply system based on basic needs, to guide reasonable consumption, and to accelerate the construction of a housing supply system with the government as the main source of supply and the market as the main source of multi-level demand. With the implementation of the policy, many loopholes are emerging, one of which is the willingness to vacate public rental housing studied in this paper. Whether tenants eventually vacate public rental housing is directly related to their willingness to vacate. At present, some tenants cheat and rely on rent. These bad behaviors not only violate the original intention of the government to implement the indemnificatory housing policy, but also hinder the sustainable development of public rental housing. Domestic and foreign scholars have made some achievements in the research on the exit model of affordable housing. There are many qualitative studies on the exit of affordable housing, but few quantitative studies ${ }^{[1-8]}$. In view of this, aiming at the problem of public rental tenants' willingness to vacate, this paper takes the condition of public rental tenants as the research object, and discusses the correlation of factors that affect tenants' willingness to vacate and resolve the confidence of their own housing. Combined with the actual situation, the author puts forward some suggestions on how to improve the exit policy of public rental housing.

\section{Questionnaire design and statistics}

\subsection{Questionnaire design}

Domestic and foreign researches on the exit mechanism of public rental housing is basically manifested in the following three aspects: unreasonable rent formulation, inadequate popularization of the legal system of public rental housing and imperfect implementation of the exit system ${ }^{\text {[9-13]. }}$. Scientific statistical methods will be used to discuss the willingness of public rental tenants to vacate and their confidence in solving their own housing problems.

The questionnaire is divided into three parts: the basic information of the respondents, the implementation of public rental housing system and the willingness to vacate public rental housing. 
Table 1. Definition and assignment of main variables

\begin{tabular}{|c|c|c|}
\hline variable & Variable definitions & The assignment of variables \\
\hline $\mathrm{x}_{1}$ & gender & $1=$ Male $2=$ Female \\
\hline $\mathrm{x}_{2}$ & age & $\begin{array}{c}1=18 \text { years old } 2=18-30 \text { years old } \\
3=31-40 \text { years old } 4=41-50 \text { years old } \\
5=51-60 \text { years old } 6=60 \text { years old or older }\end{array}$ \\
\hline $\mathrm{x}_{3}$ & education level & $\begin{array}{l}\text { niddle school and below } 2=\text { High school/ secondary } \\
\text { chool / Technical school } 3=\text { Undergraduate/junior } \\
\text { College } 4=\text { Master and above }\end{array}$ \\
\hline $\mathrm{X}_{4}$ & $\begin{array}{r}1=\mathrm{g} \\
4=\mathrm{S} \\
7=\end{array}$ & $\begin{array}{l}\text { government, social organization,public institution } \\
2=\text { Corporate staff } 3=\text { Worker, sales clerk, waiter } \\
\text { Science, education, culture and health professional } \\
\quad 5=\text { freelancer } 6=\text { self-employed } \\
\text { Unemployed, laid-off worker } 8=\text { retiree } 9=\text { Other }\end{array}$ \\
\hline $\mathrm{x}_{5}$ & average monthly household income & $\begin{array}{c}1=1000 \text { yuan below } 2=1001 \text { yuan }-2000 \text { yuan } \\
3=2001 \text { yuan-3000 yuan } 4=3001 \text { yuan }-4000 \text { yuan } \\
5=4001 \text { yuan or more }\end{array}$ \\
\hline $\mathrm{x}_{6}$ & people & $\begin{array}{c}1=1 \text { person } 2=2 \text { people } 3=3 \text { people } 4=4 \text { people } \\
5=5 \text { or more people }\end{array}$ \\
\hline $\mathrm{x}_{7}$ & housing construction area & $\begin{array}{l}1=40 \text { square meters or less } 2=41-50 \text { square meters } \\
\qquad \begin{array}{l}3=51-60 \text { square meters } \\
4=61-70 \text { square meters }\end{array}\end{array}$ \\
\hline $\mathrm{x}_{8}$ & $\begin{array}{c}\text { understanding of the nature of public rental } \\
\text { housing }\end{array}$ & $\begin{array}{l}1=\text { Welfare housing } 2=\text { transitional housing, with } \\
\text { contract period }\end{array}$ \\
\hline $\mathrm{X}_{9}$ & $\begin{array}{l}\text { public rental housing rent is the amount of } \\
\text { similar housing rent around }\end{array}$ & $\begin{array}{c}1=30 \% \text { or less } 2=30 \%-40 \% \\
3=40 \%-50 \% 4=60 \%-70 \% 5=70 \% \text { or less }\end{array}$ \\
\hline $\mathrm{x}_{10}$ & $\begin{array}{l}\text { satisfaction with the eligibility criteria for public } \\
\text { rental housing }\end{array}$ & \\
\hline $\mathrm{X}_{11}$ & $\begin{array}{c}\text { satisfaction with fairness and impartiality in the } \\
\text { distribution process }\end{array}$ & \\
\hline $\mathrm{x}_{12}$ & $\begin{array}{l}\text { overall satisfaction with the efficiency of the } \\
\text { entire process }\end{array}$ & $\begin{array}{l}1=\text { lowest } \\
5=\text { highest }\end{array}$ \\
\hline $\mathrm{x}_{13}$ & $\begin{array}{c}\text { understanding of the policy of exiting affordable } \\
\text { housing }\end{array}$ & $1-5$ means the degree is progressive \\
\hline $\mathrm{x}_{14}$ & confidence in solving their housing problem & \\
\hline $\mathrm{x}_{15}$ & $\begin{array}{l}\text { confidence in the implementation of exit system } \\
\text { policies }\end{array}$ & \\
\hline $\mathrm{X}_{16}$ & willingness to vacate & $\begin{array}{c}1=\text { Follow others } 2=\text { No matter what, I don't vacate } \\
3=\text { The government proposes preferential } \\
\text { conditions, I will vacate } 4=\text { It depends on } 5=\text { Other }\end{array}$ \\
\hline
\end{tabular}

In order to ensure the scientific nature of the investigation, the subjects of the questionnaire are the residents of the three public rental housing communities in Wuhan (the homeland of Nanhu New City in Wuchang District, Mahu New Village in Wuchang District, and Huimin homeland in Jiangan District). Sampling survey and individual interviews were conducted for residents of various age groups and occupations. A total of 461 questionnaires were collected, of which 448 were qualified questionnaires, excluding non-qualified questionnaires with more than 3 unfilled options, and the efficiency of the questionnaires was $97.2 \%$.

\subsection{Descriptive statistics}


According to the survey, $36.3 \%$ of the respondents were male.Female respondents accounted for $63.7 \%$.Age under 40 accounted for $21.1 \%$, age between 41 and 50 accounted for $12.4 \%$, age between 51 and 60 accounted for $27.4 \%$, and age over 60 accounted for $39.1 \%$. The number of tenants over the age of 50 accounted for $66.5 \%$ of the total sample of this survey, so it can be found that the age level of public rental tenants is generally high.

Secondly, the education level of interviewees is generally not high, and the level of education in middle school and below accounts for about half, while the level of master and above is almost none.The largest proportion of respondents were retirees (see table 2), while the number of government /public institution/social organization workers and self-employed was not large.

Table 2. occupation distribution of interviewees

\begin{tabular}{ccccc}
\hline Career & Frequency & $\begin{array}{c}\text { percenta } \\
\text { ge }\end{array}$ & $\begin{array}{c}\text { Effective } \\
\text { percentage }\end{array}$ & $\begin{array}{c}\text { Cumulative } \\
\text { percentage }\end{array}$ \\
\hline government, social organization, public & 17 & $3.80 \%$ & $3.80 \%$ & $3.80 \%$ \\
institution & 29 & $6.5 \%$ & $6.5 \%$ & $10.30 \%$ \\
corporate staff & 63 & $14.1 \%$ & $14.1 \%$ & $24.30 \%$ \\
worker, sales clerk, waiter & 7 & $1.60 \%$ & $1.60 \%$ & $25.90 \%$ \\
science, education, culture and health & & & & $34.80 \%$ \\
professional & 40 & $8.90 \%$ & $8.90 \%$ & $37.50 \%$ \\
freelancer & 12 & $2.70 \%$ & $2.70 \%$ & $47.50 \%$ \\
self-employed & 45 & $10 \%$ & $10 \%$ & $97.30 \%$ \\
unemployed, laid-off worker & 223 & $49.80 \%$ & $49.80 \%$ & $100 \%$ \\
retiree & 12 & $2.70 \%$ & $2.70 \%$ & $100 \%$ \\
other & 448 & $100 \%$ & & $10 \%$ \\
total & & &
\end{tabular}

The majority of interviewees were families of two or three, accounting for $71.3 \%$.It can be found that the household income of general public rental housing tenants is lower than the normal level, and their life is relatively difficult.But statistically, the number of households with four or more is more than $10 \%$, not a minority. The housing area of interviewees is unevenly distributed, and more than $40 \%$ of the interviewees' housing area is concentrated between 40 and 50 square meters. It can be seen from the data that the overall living area of public rental is relatively small, and there is no housing above 70 square meters.

Among the people's understanding of the nature of public rental housing, $10.9 \%$ did not have a solid and qualitative understanding of the nature of public rental housing. The public rental housing is considered as a transitional solution to the housing problem, and they will moved out when the contract expires, accounting for $79 \%$ of the total sample. In view of this, most of the surveyed residents have a correct understanding of the nature of public rental housing, and about $20 \%$ of the surveyed residents have a biased perception of public rental housing.In the satisfaction survey on public rental housing related issues, we found that the majority of respondents feel dissatisfied or ok, accounting for about $70 \%$.

Respondents who understand exit affordable housing policies accounted for only $15.6 \%$, less than $20 \%$.nearly half don't understand public rental housing exit policy completely.

If the conditions of vacating public rental housing are satisfied, chose "reach the standard of income,follow the governments " accounted for $28.4 \%$, and chose " reach the standard of income, never vacate" accounted for $6.1 \%$, "if the government provide some favorable conditions(such as transition rent subsidies for check-out, rewards, etc.), I will vacate " accounted for $23.7 \%, 26 \%$ thought it depended on, $26 \%$ had other ideas, $6.1 \%$ did not want to vacate at all.

\section{Modeling and results}

\section{1 model specification}

Logistic regression model is a mathematical statistical method. In this paper, the Stata13 software is 
used for regression analysis of the survey data. The actual values taken by dependent variables are irrelevant, although larger values are assumed to correspond to "higher" results. The conditional distribution of the dependent variables for a given random effect is also assumed to be a successful probability polynomial. Which is determined by the logistic cumulative distribution function. It is a stochastic effect model estimated by the maximum likelihood method. The basic forms of the model are as follows:

$$
\operatorname{Pr}\left(y_{i t}>\mathrm{k} \mid \mathrm{K}, X_{i t}, v_{i}\right)=\mathrm{H}\left(X_{i t} \beta+v_{i}-K_{k}\right)
$$

$\mathrm{t}=1,2,3 \ldots \mathrm{n}_{\mathrm{i}}$, vi are independent and equal distributed $\mathrm{N}\left(0, \sigma_{v}{ }^{2}\right), \mathrm{i}=1,2,3 \ldots \mathrm{n}$. When $\mathrm{K}$ is the number of possible outcomes, $\mathrm{k}$ is a series of tangent points; and $\mathrm{H}(\bullet)$ is a logistic cumulative distribution function. From the above, we can speculate that $\mathrm{y}_{i t}$ is the probability of observing the variable $\mathrm{k}$.

$$
\begin{aligned}
p_{i t k} \equiv \operatorname{Pr}\left(y_{i t}=\mathrm{k} \mid \mathrm{K}, X_{i t}, v_{i}\right) & =\operatorname{Pr}\left(K_{k-1}<X_{i t} \beta+v_{i}+\varepsilon_{i t} \leq K_{k}\right)=\operatorname{Pr}\left(K_{k-1}-X_{i t} \beta-v_{i}<\varepsilon_{i t} \leq K_{k}-X_{i t} \beta-v_{i}\right) \\
& =\mathrm{H}\left(K_{k}-X_{i t} \beta-v_{i}\right)-\mathrm{H}\left(K_{K-1}-X_{i t} \beta-v_{i}\right) \\
& =\frac{1}{1+\exp \left(-K_{k}+X_{i t} \beta+v_{i}\right)}-\frac{1}{1+\exp \left(-K_{k-1}+X_{i t} \beta+v_{i}\right)}
\end{aligned}
$$

\subsection{Model test}

First, a collinear test of 14 variables that do not include $\mathrm{x}_{16}$ (willingness to vacate) and $\mathrm{x}_{14}$ (confidence in solving their own housing problems) is shown in Table 3. According to the VIF value in the table, all variables are not collinear. So the binomial model is established.

Table 3. Collinear test

\begin{tabular}{cccccccc}
\hline variable & $\mathrm{x} 12$ & $\mathrm{x} 2$ & $\mathrm{x} 4$ & $\mathrm{x} 11$ & $\mathrm{x} 3$ & $\mathrm{x} 10$ & $\mathrm{x} 7$ \\
\hline VIF & 2.16 & 2.03 & 1.88 & 1.57 & 1.56 & 1.5 & 1.45 \\
$1 / \mathrm{VIF}$ & 0.4639 & 0.4916 & 0.5313 & 0.6376 & 0.6418 & 0.6649 & 0.6888 \\
\hline variable & $\mathrm{x} 6$ & $\mathrm{x} 5$ & $\mathrm{x} 15$ & $\mathrm{x} 1$ & $\mathrm{x} 13$ & $\mathrm{x} 9$ & $\mathrm{x} 8$ \\
\hline $\mathrm{VIF}$ & 1.29 & 1.15 & 1.09 & 1.09 & 1.07 & 1.07 & 1.03 \\
$1 / \mathrm{VIF}$ & 0.7745 & 0.8713 & 0.919 & 0.9215 & 0.9326 & 0.9343 & 0.9662 \\
\hline
\end{tabular}

\subsection{Model regression results}

Taking X16 (willingness to vacate), $\mathrm{X}_{14}$ (confidence in solving their own housing problem) as dependent

\begin{tabular}{|c|c|c|c|c|c|c|c|}
\hline \multirow{2}{*}{ variable } & \multicolumn{3}{|c|}{ Model one } & & \multicolumn{3}{|c|}{ Model two } \\
\hline & coefficient & $\mathrm{z}$ & $\mathrm{P}>|\mathrm{z}|$ & & coefficient & $\mathrm{z}$ & $\mathrm{P}>|\mathrm{z}|$ \\
\hline $\mathrm{x}_{1}$ & -0.2485 & -1.12 & 0.265 & $\mathrm{x}_{1}$ & 0.1537 & 0.67 & 0.503 \\
\hline $\mathrm{x}_{2}$ & 0.0749 & 0.72 & 0.47 & $\mathrm{x}_{2}$ & $-0.3568 * * *$ & -3.24 & 0.001 \\
\hline $\mathrm{x}_{3}$ & 0.0762 & 0.45 & 0.65 & $\mathrm{x}_{3}$ & -0.0266 & -0.16 & 0.874 \\
\hline $\mathrm{X}_{4}$ & $-0.093 *$ & -1.55 & 0.121 & $\mathrm{X}_{4}$ & 0.0671 & 1.08 & 0.28 \\
\hline $\mathrm{X}_{5}$ & 0.1454 & 1.27 & 0.203 & $\mathrm{X}_{5}$ & -0.0987 & -0.85 & 0.393 \\
\hline $\mathrm{x}_{6}$ & $0.2295^{*}$ & 1.84 & 0.066 & $\mathrm{x}_{6}$ & -0.0398 & -0.31 & 0.755 \\
\hline $\mathrm{x}_{7}$ & $0.0328 * *$ & 2.22 & 0.027 & $\mathrm{x}_{7}$ & $-0.0275^{*}$ & -1.83 & 0.068 \\
\hline $\mathrm{X}_{8}$ & $0.7185^{* *}$ & 2.18 & 0.03 & $\mathrm{x}_{8}$ & 0.1495 & 0.43 & 0.669 \\
\hline $\mathrm{X}_{9}$ & -0.1278 & -1.08 & 0.278 & $\mathrm{X}_{9}$ & $-0.2623 * *$ & -2.22 & 0.026 \\
\hline $\mathrm{x}_{10}$ & 0.1542 & 0.98 & 0.329 & $\mathrm{x}_{10}$ & 0.0993 & 0.63 & 0.527 \\
\hline $\mathrm{x}_{11}$ & -0.1382 & -0.93 & 0.355 & $\mathrm{x}_{11}$ & -0.0458 & -0.31 & 0.755 \\
\hline $\mathrm{X}_{12}$ & 0.1686 & 1.12 & 0.262 & $\mathrm{X}_{12}$ & -0.0682 & -0.45 & 0.654 \\
\hline $\mathrm{x}_{13}$ & $0.4462 * * *$ & 4.78 & 0 & $\mathrm{X}_{13}$ & $0.2142 * *$ & 2.23 & 0.026 \\
\hline $\mathrm{X}_{15}$ & $-0.4293 * * *$ & -3.23 & 0.001 & $\mathrm{X}_{15}$ & $-0.6023 * * *$ & -4.33 & 0 \\
\hline $\mathrm{X}_{14}$ & 0.1647 & 1.02 & 0.306 & $\mathrm{x}_{16}$ & -0.0072 & -0.04 & 0.965 \\
\hline
\end{tabular}
variable and the other 15 variables as independent variables, an ordered Logistic model is established (see table 4).

Table 4. Regression results of ordered Logistic Model 


$\begin{array}{ll}\text { Number of obs }=448 & \text { Number of obs }=448 \\ \text { LR chi2 }(15)=72.59 & \text { LR chi2 }(15)=54.67 \\ \text { Pseudo R2 }=0.0778 & \text { Pseudo R2 }=0.0670\end{array}$

In this paper, the confidence levels are $20 \%, 10 \%$ and $1 \%$, excluding the factors that do not meet the conditions, we can do the following analysis: from model I, $\mathrm{x}_{16}$ (willingness to vacate) is negatively correlated with $\mathrm{x}_{15}$ (confidence in the implementation of exit system policies) and $\mathrm{x}_{4}$ (profession). There is a positive correlation with $\mathrm{x}_{6}$ (people), $\mathrm{x}_{7}$ (housing construction area), $\mathrm{x}_{8}$ (understanding of the nature of public rental housing)and $\mathrm{x}_{13}$ (understanding of the policy of exiting affordable housing).

From model 2, we know that $\mathrm{X}_{14}$ (the confidence in solving their housing problems) is negatively correlated with $\mathrm{x}_{2}$ (age), $\mathrm{x}_{7}$ (housing construction area), $\mathrm{x} 9$ ( public rental housing rent)and $\mathrm{x}_{15}$ (confidence in the implementation of exit system policies).Positively related to $\mathrm{X}_{13}$ (understanding of the policy of exiting affordable housing), Among them, $\mathrm{x}_{15}$ can significantly influence $\mathrm{x}_{14}$, to explainwhether the government can effectively implement the policy of reclaiming the housing of non-eligible public housing tenants, which is directly related to whether the residents have confidence in solving their own housing problems.

So from regression model and data chart we can know that when the interviewees are older, the higher the rent of public rental housing, the higher the daily living expenses of the tenants, the less confidence they have in solving their housing problems, the more difficult it is to vacate.

\subsection{Discussion}

1) The less confidence respondents have in the implementation of exit policies, the more reluctant they are to vacate. When the exit policy cannot be implemented quickly and effectively, it means that the exit qualification examination is not rigorous and the exit notice is not timely.However, people are lazy and self-interested, and always tend to do what is good for them. When there is no pressure from outside to vacate, tenants will choose not to vacate.

2) The larger the construction area, the more willing to vacate. The larger the space, the larger the housing expenses, and the heavier the rent burden for the tenants, means that the tenants have to reduce their expenses in other aspects and even reduce the expenses of necessities. Therefore, the larger the area is, the easier it is for the tenants to vacate.

3 ) the more deeply the interviewees understand the nature of public housing and the exit policy, the more willing to vacate. If they understand the system of public rental housing, and the degree of punishment of people who violate the system, They will not break the law. At the same time, when the tenants' living conditions are improved and the conditions for vacating are satisfied, they think that the living environment of public rental housing is no longer suitable for their own living, they tend to vacate.

4)The older the interviewees are, the higher the rent of public rental housing is, and the less confident they are in solving their housing problems. As they get older, their career and income is limited, and the cost of health care or other necessities is higher, and of course there is no extra money to fix the housing problem.

\section{Conclusion}

1) The willingness to vacate public rental housing is closely related to the respondents' confidence in the implementation of the exit policy, their understanding of the exit policy of indemnificatory housing, the nature of public rental housing and the area of housing.

2) On the surface, the government with low policy implementation will promote the development of society, that is, the residents cannot enjoy the government's welfare policy, so it can only rely on the residents to solve the housing problem by themselves.However, in a deep sense, the government with low policy enforcement and a large number of marginalized people entering the society are not 
conducive to social harmony and stability, which will increase many factors of social instability and lead to popular unrest.

3) To fundamentally solve the problem of vacating public rental housing, it is necessary to improve the social security system so that residents can solve the housing problem themselves. When they have the confidence to solve their own housing problem, with the help of the government to strive for their own goals, they will certainly achieve the goal of owning their own houses.

\section{References}

[1] Dockery A M., Ong R., Whelan S., Wood G A. The Relationship between Public Housing Wait Lists, Public Housing Tenure and Labour Market Outcomes. National Research Venture 1 Research Paper 9, Australian Housing and Urban Research Institute, 2008.

[2] Zhang Jinjun, Han Meigui. Game Analysis on the exit Mechanism of Urban Low-Rent Housing [J] .Journal of Engineering Management, 2013 (1): 73-77.

[3] Whelan S. The Dynamics of Public Housing Tenure in Australia. Australian Economic Review, 2009, 42(2): 155-176.

[4] Li Guang, Xu Yan. The Way to Solve the "Difficult Exit" of Affordable housing [J]. Shanghai Real Estate, 2012, (2): 29-31.

[5] He Ling, Guo Shizheng. The exit Mechanism of low Rent Housing Security: current situation, problems and Countermeasures: a case of Shanghai [J]. East China Economic Management 2010, (2): $1-4$.

[6] Wei Liyan. Research on the admittance and exit mechanism of fair distribution of affordable housing [J]. South East academic: 2012, (3): 40-48.

[7] Zhou Xiaohan, You Peng. Problems and countermeasures of the exit Mechanism of low-rent housing at the present stage [J]. China real estate,2012(3):19-21.

[8] Lu Shen. Research on the exit management of affordable housing in China [D]. Nanjing: Nanjing Forestry University, 2014, (4)

[9] Pan Yuhong, Zeng Yiwen, sun qi, et al. Study on the willingness to vacate public rental housing and policy recommendations -- a case of chongqing [J]. Building economy 2015(1):103-107.

[10]Ding Xiaoxin, Yin Wei. Problems and Solutions to the exit Mechanism of Safe Housing in Jilin Province[J]. Journal of Jilin Institute of Architectural Engineering, 2014, (4): 78-81.

[11]Wang Jianqiang. Analysis of the status quo and countermeasures of low-rent housing construction in China[J].Journal of Changchun University of Science and Technology(Social Science Edition),2012,25(3):37-40.

[12]Han Wei. The Construction of the Admission and exit Mechanism of the Housing Security Law under the Information Horizon[J].Journal of Chifeng College(Chinese Philosophy and Social Sciences),2011,32(6):44-47.

[13]Peng Jing, Duan Yang. Research on the exit Mechanism of low-rent housing in China [J]. Enterprise Research, 2011, (10): 143-144. 